\title{
Omissões e seletividades da ciência política brasileira: \\ lacunas temáticas e seus problemas sócio-epistêmicos
}

Omissions and selectivities in Brazilian political science: thematic gaps and its social-epistemic problems

A ciência política brasileira vive um momento de intensa avaliação crítica e efervescente reflexão metacientífica. Em sua primeira seção, este artigo apresenta e explica esse contexto. Em seguida, propõe uma contribuição ao debate, cingida ao tema da seletividade da pesquisa científico-política brasileira, assim qualificada como atributo que a conduz a uma relativa omissão quanto a investigações dedicadas às práticas de ativismo, protesto e confronto. Sob esse amplo campo temático, ambiciona-se a consecução de dois objetivos, revestidos, respectivamente, de naturezas preponderantemente teórica e empírica.

O primeiro, cumprido ao longo da segunda seção, atém-se à proposição de uma tipologia alegórica que logrará classificar a produção intelectual brasileira no campo da ciência política. O enfoque recai sobre os objetos estudados, seja em sentido estático (parlamento, movimentos sociais, fóruns participativos etc.), seja em acepção dinâmica (eleições, eventos de protestos, fluxos de opinião etc.). Sob a constatação de que o objeto precípuo da ciência política é a relação social de poder, pretende-se classificar a pesquisa brasileira com base nos "lugares" ou conjuntos específicos de relações para os quais os cientistas dirigem seus olhares quando querem entender essa relação, inobstante a

É professor adjunto da Faculdade de Ciências Sociais e coordenador do Programa de Pós-Graduação em Ciência Política da Universidade Federal de Goiás (UFG). E-mail: franciscotavares@ufg.br.

** É mestrando em sociologia na Instituto de Estudos Sociais e Políticos da Universidade do Estado do Rio de Janeiro (lesp-Uerj) e pesquisador do Núcleo de Pesquisa sobre Ativismo e Lutas Sociais em Perspectiva Comparada (Proluta/UFG). E-mail: ian_gyn@hotmail.com. 
natureza do enfoque, se explicativa, interpretativa ou prescritiva. Propõe-se que é possível e válido discernir-se os trabalhos publicados em nossa ciência política a partir da ênfase que conferem em: 1) um jogo orientado ao exercício de influência sobre o Estado; 2) processos decisórios formais abertos à participação cidadã direta; 3) fluxos comunicacionais que circulam na esfera pública; 4) lutas e conflitos deduzidos em práticas de confronto. O escopo desse esforço situado entre a alegoria e a tipologia - sem a ambição, destarte, de conformar-se como taxonomia - reside em inventariar as potencialidades e insuficiências de cada variante apresentada. Não se ambiciona, com efeito, afirmar-se a preferência ou superioridade de nenhuma delas.

O objetivo complementar deste texto, a ser cumprido em seção específica, reside em uma aferição empírica. A observação é centrada sobre os periódicos classificados no estrato A pela Coordenação de Aperfeiçoamento de Pessoal de Nível Superior (Capes) entre 2007 e 2013. Colhe-se, nesse universo, a distribuição dos tipos-alegorias em meio ao conjunto de publicações que vieram a lume nos últimos anos. O achado que se pretende discutir é o de que as práticas de confronto e os protestos sociais têm sido os assuntos mais negligenciados pela ciência política brasileira, o que dificulta a compreensão de aspectos fundamentais do poder em nossa sociedade.

\section{Ciência política brasileira: tempo de balanços, sínteses e sistematizações}

A ciência política produzida no Brasil experimenta, ao menos desde o início do século XXI, uma significativa expansão, observada em sua crescente afirmação epistêmica e, igualmente, na contínua consolidação de sua institucionalização. Vive-se, com efeito, um contexto favorável à produção de pesquisas orientadas por fôlego metacientífico e edificadas a partir de indagações que ensejam a apresentação de reflexões, dados ou indicadores atinentes a elementos como a expansão da pós-graduação na área, o surgimento de novos problemas de pesquisa, as tendências metodológicas comumente implementadas, os referenciais teóricos mais influentes, a oscilação positiva do volume de publicações ou a evolução do impacto provocado pelo conhecimento científico-político brasileiro em âmbito internacional. É seguro propor que expansão e balanço reflexivo se definam, nos termos abaixo comentados, como traços específicos à contemporânea época da ciência política brasileira. 
Quanto à dimensão institucional da expansão, é suficiente constatar que há 43 programas de pós-graduação stricto sensu em atividade na área de ciência política e relações internacionais no Brasil, dos quais 24 iniciaram-se a partir de $2010^{1}$ (Capes, 2015). O impacto da produção acadêmica brasileira na seara da ciência política e das relações internacionais experimenta, igualmente, indubitável elevação de patamar nos últimos anos. O indicador Scimago, por exemplo, acusa que o número anual de documentos provenientes do Brasil até 2006 jamais foi superior a vinte. A partir de 2010, o mesmo valor nunca foi inferior a oitenta, oscilação positiva que representou um salto do posicionamento do país vis-à-vis outras nações latino-americanas, as quais ainda não ultrapassaram a marca de sessenta (Scimago, 2015).

Uma área do conhecimento que cresce em institucionalização e impacto defronta-se com a necessidade e com o ensejo de postar-se diante do espelho. Já com séries significativas e um volume de produção suficientemente vasto, é possível perquirir os meandros do seu itinerário, em especial sob os prismas temático e metodológico. Adiante, mencionam-se exemplos de relevantes estudos recentes que, nesse contexto, debruçam-se sobre a ciência política brasileira.

Ainda em 1997, no prelúdio da expansão observada a partir do século XXI, Maria Cecília S. Forjaz publicou um trabalho de cunho histórico sobre o papel específico e pioneiro de duas instituições, quais sejam, o antigo Instituto Universitário de Pesquisas do Rio de Janeiro (Iuperj) e o Departamento de Ciência Política da Universidade Federal de Minas Gerais (DCP/UFMG), no processo de implementação da ciência política como um ramo suficientemente autônomo do saber acadêmico científico-social no Brasil (Forjaz, 1997). Cuida-se de um texto que, sem favores, inaugura a era das pesquisas metacientíficas no campo da política no Brasil, hoje em seu apogeu.

Em 2000, João Feres Júnior questionou os limites e a insuficiência do legado estadunidense, em especial no que concerne ao insulamento da teoria política, sobre o âmbito da ciência política brasileira (Feres Júnior, 2000). Em 2005, Gláucio Soares apresentou o argumento de que haveria um "calcanhar metodológico" na produção dos cientistas políticos brasileiros, assim manifestado em uma escassa adoção de técnicas de pesquisa quantitativas e em um emprego pouco rigoroso de técnicas qualitativas. $\mathrm{O}$ autor atribuiu à maior porção da produção brasileira o signo da "ausência de métodos e de rigor" (Soares, 2005).

1 No período compreendido entre 2000 e 2014, foram criados 29 cursos. 
Cinco anos mais tarde, uma obra canônica na autocompreensão da ciência política brasileira seria editada sob os auspícios da Associação Nacional de Pós-Graduação e Pesquisa em Ciências Sociais (Anpocs). O livro, introduzido por uma revisão da trajetória percorrida pelo campo no Brasil (Lessa, 2010), apresentou rigorosas exposições sobre o estágio de temas tão relevantes e diversificados como, dentre outros, teoria política (Araújo e Assumpção, 2010), estudos legislativos (Limongi, 2010) e política comparada (Amorim Neto, 2010). O primeiro decênio do século XXI parecia, como se infere desses exemplos, decorar o cenário em que um debate metodológico, referenciado em distintos juízos sobre a influência de um fazer científico hegemônico nos Estados Unidos, seria representado em solo brasileiro no período seguinte.

Assim, já em 2011, Renato Lessa deu continuidade ao autoentendimento da área no Brasil e constatou a lacuna quanto à produção acadêmica de uma história da ciência política. O próprio texto auxiliou a superar tal ausência, em uma apresentação orientada a avançar contra as herméticas fronteiras que apartam estudos supostamente pré-científicos ou interpretativos, em contraposição a pesquisas empíricas, autoidentificadas como explicativas e científicas. A síntese sugerida pelo autor prescrevia uma inflexão na marcha da influência anglófona e sugeria que "a reaproximação com as humanidades e com as ciências sociais pode ser uma bela alternativa para que continuemos a dar curso a algo indelevelmente humano: falar, de objetos" (Lessa, 2011). Em 2012, Marcelo Moreira valer-se-ia da influência anglófona para, desta feita, infirmar aqueles que importavam o empirismo líquido de reflexão teórica. $\mathrm{Na}$ esteira de Terence Ball, o artigo somou-se ao que se entendia como um "retorno à teoria política", experimentado nos Estados Unidos ao menos desde a década de 1970 do século XX (Moreira, 2012). Em 2013, Jairo Nicolau e Lilian Oliveira integraram-se ao debate reflexivo da ciência política brasileira e, com estribo em um robusto levantamento empírico, diagnosticaram a prevalência de pesquisas adeptas de abordagens empírico-quantitativas no Brasil, o que indicou, portanto, uma reversão do cenário detectado nove anos antes por Gláucio Soares. Os autores foram além e aderiram a uma primeira e recente onda de estudos metacientíficos que procuram medir não apenas as técnicas de pesquisa, escolhas metodológicas e estágio das subdisciplinas tradicionais, mas, adicionalmente, os temas e objetos preponderantes (Nicolau e Oliveira, 2013). Nesse diapasão, Danusa Marques e Carlos Machado apresentaram, em 2014, uma pesquisa cujo cerne cingiu-se 
às ciências sociais, inobstante guardasse uma abordagem apta à formulação de conclusões acerca do modo como a ciência política brasileira lida com um tema específico, nomeadamente, o das desigualdades (Marques e Machado, 2014). E, ainda naquele ano, Daniela Mussi apresentou um estudo sobre a recepção, em solo brasileiro, dos estudos de cultura política (Mussi, 2014).

Já em 2015, foi defendida uma tese de doutorado por Fernando Leite na Universidade Federal do Paraná que, de modo abrangente e rigoroso, passou em revista inúmeros aspectos da produção científico-política no brasil (Leite, 2015). O trabalho pode ser caracterizado como a síntese dos esforços reflexivos pretéritos concomitante ao signo de um novo momento na metaciência política brasileira, definido por pesquisas revestidas de fôlego e amplitude sem par nas pioneiras produções dos anos anteriores.

Finalmente, também no ano de 2015 foi apresentado um artigo redigido por Fernando Limongi, Maria Hermínia Tavares de Almeida e Andrea Freitas, cujo escopo consistiu em uma narrativa da trajetória da ciência política brasileira, lastreada em minudente e rigorosa escavação sobre artigos científicos publicados desde 1988. O argumento principal do texto dá conta de que os últimos seis lustros experimentaram a consolidação do neoinstitucionalismo na versão nacional da disciplina. Confere-se destaque ao papel representado por Bolívar Lamounier e Sérgio Abranches nesse processo em que estudos de sociologia política teriam cedido terreno à abordagem centrada nas instituições. A progressiva estabilização do neoinstitucionalismo como corrente principal da ciência política brasileira conferiu à versão nativa dessa vertente teórica os predicados de "originalidade e características próprias" (Limongi et al., 2015). É certo que essa narrativa ofertada pelos autores se revela irretocável e que se firmou, de fato, uma hegemonia neoinstitucionalista ao longo dos últimos anos no Brasil. Há que se indagar, todavia, os limites e problemas epistêmicos decorrentes desse quadro fático. Pretende-se, aqui, avançar sobre tal seara, suprindo, ainda que limitadamente, essa lacuna.

As seções seguintes se inserem neste contexto de autoavaliação crítica e tencionam contribuir para a compreensão que a ciência política brasileira tem a seu próprio respeito. Em compasso com as tendências mais recentes, efetivou-se uma pesquisa concentrada de modo primaz sobre os objetos e temas contidos nos trabalhos acadêmicos que se constituíram como base empírica do estudo. Assim, as opções metodológicas e os referenciais teóricos que os definem comparecem apenas por via oblíqua. 


\section{Quatro tipos-alegorias da ciência política no Brasil}

Cada jovem que se inicia no estudo da ciência política aprende, ainda nos primeiros dias, que a disciplina se dedica à compreensão de uma específica relação social, qual seja, a do poder ${ }^{2}$. A aparente simplicidade do objeto se esvai no instante seguinte, quando se nota que o significante em questão se projeta em significados não apenas múltiplos, mas díspares, em uma profusão de definições que entrecortam o pensamento de autores como Weber, Arendt, Parsons, Bourdieu, Offe, Foucault, Habermas e incontáveis outros. Ao problema teorético da polissemia que acompanha o significado de poder, soma-se a questão fática dos espaços sociais privilegiados pelo estudioso da política em suas investigações. Entre o Estado em sentido weberiano e os micropoderes de Foucault, o olhar do iniciante ou mesmo dos experts em ciência política não pode se reconfortar com a certeza de um objeto claro, estável e bem delimitado, como ocorre em áreas do conhecimento que, segundo a epistemologia de Kuhn, seriam "paradigmáticas" (Kuhn, 1996) 3 .

Este texto ancora-se na premissa de que um olhar sobre os temas e objetos da ciência política brasileira que seja complementar às classificações próprias às subdisciplinas tem o potencial de agregar informações novas e relevantes para o diagnóstico do estado da arte do campo. Assume-se, pois, que a divisão do trabalho acadêmico em áreas específicas não é, sempre ou necessariamente, suficiente para a estabilização da disciplina em grau de compatibilidade com as múltiplas possibilidades fornecidas por um polissêmico e quase onipresente objeto. É possível, por exemplo, atravessar as fronteiras entre política comparada, relações internacionais, teoria política e política nacional, com inerte foco sobre as instituições e a reunião de esforços para exercício de influência ou controle direto sobre os processos decisórios em espaços oficiais.

A compreensão do que se estuda e de quais são os temas preferidos pela ciência política brasileira pode ser complementada por abordagens que, antes de infirmarem, procuram complementar as classificações referenciadas em

2 Vê-se, por exemplo, nas primeiras linhas do Oxford handbook of political science, que "politics is the constrained use of social power" (Goodin, 2009, p. 5). Desnecessário dizer que ainda está por se encontrar manifestação teórica ou empírica de poder que seja ilimitada ou irrestrita. Segue, pois, que a mencionada definição expressa, integralmente, a ideia de política como a relação social de poder.

3 Há quem, contrariamente, sugira que a ciência política seja paradigmática. Uma aposta na teoria da escolha racional como paradigma kuhniano para a ciência política pode ser encontrada em Pirozelli et al. (2012). Entretanto, este artigo assume a noção prevalecente de que a ciência política não é paradigmática. 
subdisciplinas ou temas já tradicionalmente associados ao campo. Neste trabalho, apresentam-se tipos, em formato alegórico, que procuram indicar o modo como um vasto conjunto de temas, aos quais influentes referenciais teóricos usualmente se associam, tem sido negligenciado pelos estudos científico-políticos no Brasil. Trata-se do universo que compreende ações como protestos de rua, sujeitos como movimentos antirregime e estratégias como a derrocada da pax liberal-democrática.

A ideia é realçar uma dimensão da política exorbitante à tríade preponderantemente associada ao conjunto de temas admitidos como pertencentes à disciplina. Enfatiza-se, assim, a conduta política alcançada pelas seguintes negativas: 1) não se orienta por interesses individuais predeterminados e não tem na reunião de esforços para influenciar ou governar o Estado a sua manifestação por excelência; 2) não adota como fronteiras do universo decisório democrático os posicionamentos em fóruns estatais abertos à sociedade civil (das consultas plebiscitárias às conferências ou conselhos); 3) tampouco entende a legitimidade do poder como função da porosidade estatal diante dos fluxos ilocucionários transitados em uma esfera pública composta de jurisconsortes livres, racionais e iguais.

Discute-se, com efeito, a lacuna definida por Breno Bringel como "miopia da política", assim enunciada como a leitura que "restringe a vida política à sua dimensão político-institucional, limitando as possibilidades de compreensão da reinvenção da política e do político a partir das práxis sociais emergentes" (Bringel, 2013)4. Em um "tempo de distúrbios e levantes”, nos termos do subtítulo de um recente livro redigido por Badiou (2012), pode ser produtiva a proposição de uma tipologia que incorpore os estudos desses eventos no âmbito da ciência política e, adicionalmente, logre contrapô-los a outros conjuntos de objetos.

Adiante, com vistas a preparar o solo teórico para a demonstração da lacuna sugerida, apresentam-se três tipos de natureza alegórica, indicativos

4 O confinamento da política ao plano institucional - e, de um modo ainda mais específico, ao Estado - denunciado por Breno Bringel comparece não apenas às variantes hegemônicas da ciência política, mas também se identifica em abordagens mais críticas, como o deliberacionismo de Habermas. Vale lembrar, nos termos de uma passagem da Teoria do agir comunicativo, que para o prócer da deliberação pública "as instituições que ancoram os mecanismos de controle do mundo da vida, tais como o dinheiro e o poder, canalizam a influência do mundo da vida para as esferas da ação organizadas formalmente [...] elas funcionam como moldura institucional que submete a manutenção do sistema às restrições normativas do mundo da vida" (Habermas, 2012, p. 334). 
daquilo que os cientistas políticos no Brasil costumam observar quando pretendem entender as relações de poder. A classificação em questão não se ambiciona taxonômica, definida por categorias exaustivamente inclusivas e mutuamente excludentes. Antes, o escopo é instigar as fronteiras da autorreflexão sobre a ciência política brasileira, por meio de tipos que simplificam, alegoricamente ${ }^{5}$, as práticas de estudo científico e institucional da política no país. De um modo muito amplo, tem-se que arquetípicos cientistas políticos, quando perguntados sobre o que estudam, poderiam oferecer variações ou combinações das seguintes respostas: 1) "eu estudo uma gincana"; 2) "eu estudo uma reunião de condomínio"; 3) "eu estudo uma cafeteria”; 4) "eu estudo o fogo no pneu”. A seguir, desenvolvem-se o conteúdo e o sentido dessas sentenças alegóricas.

Alguns esclarecimentos prévios são necessários para que a classificação alegórica aqui proposta se revele pertinente, isto é, não seja redundante em relação a categorias já existentes, e clara, isto é, possa ser identificada em situações concretas. O referencial teórico e a técnica de pesquisa adotados não são os critérios primazes na identificação de uma pesquisa com um tipo específico. A ênfase, reitera-se, recai sobre o objeto. Assim, será possível notar que os estudos de política como gincana tendem a se valer com maior frequência do arcabouço teórico do neoinstitucionalismo da escolha racional ou de técnicas de pesquisa quantitativas. Isso, contudo, não impede que existam trabalhos pertencentes a esse tipo que se filiem a outras teorias ou que se valham de técnicas de pesquisa qualitativas ${ }^{6}$. Do mesmo modo, há trabalhos que enxergam a política como "fogo no pneu" e se filiam à teoria da escolha racional ou utilizam dados quantificáveis, embora isso não seja o mais comum. O que

5 Entende-se que a relação entre ciência e alegoria seja de mútua influência. A projeção em metáforas e abstrações dos conceitos e pensamentos científicos é um recurso cognitivo que permite a ampliação do espectro de elementos compreendidos, associada, dialeticamente, à simplificação de contextos que, tamanha a complexidade, podem se revelar turvos. Sobre essa relação, conferir o seguinte excerto: "A alegoria emergiu quando o racionalizar sistemático foi aplicado às narrativas culturais arcaicas; a ciência emergiu quando as atitudes abstraentes da leitura alegórica foram estendidas para a contemplação do mundo natural. E desde Platão sempre houve essa recorrência, essa corrente histórica em alternância: primeiro a ciência se desenvolve a partir da alegoria; e, então, a alegoria se desenvolve a partir da ciência" (Clarke, 1996, tradução nossa).

6 Exemplo de estudo ancorado em arcabouço teórico divergente do neoinstitucionalismo, mas concentrado no jogo eleitoral ou parlamentar (aqui entendido como compatível com a alegoria da gincana) pode ser visto em Miguel e Feitosa (2009).

7 Para uma discussão repleta em exemplos de estudos sobre protestos e movimentos sociais que se ancoram em um arcabouço olsoniano, conferir o quarto capítulo de Theories of politicial protest and social movements (Opp, 2009). 
define cada tipo, portanto, é o direcionamento do olhar, em sentido estático e dinâmico, do pesquisador que pretende estudar relações sociais de poder. A seguir, explicam-se os tipos e seus atributos, potenciais e limitações.

\section{A política como uma gincana}

O repertório pedagógico de escolas e instituições esportivas no Brasil registra fartamente a organização de gincanas em que equipes compostas por crianças ou jovens competem em busca de uma premiação. A lógica dessas competições-brincadeiras é simples e amplamente conhecida: grupos definidos de modo aleatório ou por afinidades se organizam e devem competir com os seus congêneres, em uma disputa conduzida por sucessivas tarefas, para as quais é assinalada uma pontuação específica, de tal sorte que ao final triunfa a equipe com maior número de pontos.

Sob um olhar mais detido, todavia, essa simplicidade tende a se esvanecer. Primeiramente, há que se considerar o jogo sob o enfoque dos problemas de coordenação interna nas equipes e da miríade de conflitos decisórios que ali ocorrem, a oscilarem da escolha do nome que o grupo terá à definição de quem cumprirá cada tarefa específica. Conflitos pela liderança interna, intrigas de ordem pessoal, padrões de relacionamento com as outras equipes e a tendência a um blame-game nos episódios de insucesso são recorrentes signos de como, sociologicamente, há muito a explicar quanto à dinâmica de coletivos estudantis organizados para a disputa de uma competição. Soma-se aos problemas de coordenação interna a plêiade de conflitos concernentes às regras da competição, à interpretação de casos controvertidos, ao modo como as equipes recebem ou não auxílios materiais e humanos externos ou às práticas que se reiteram ao longo de sucessivas edições de uma mesma gincana, gerando algo como um path dependence lúdico. É possível, ainda, atentar para os cálculos exercidos pelas equipes e para as operações estratégicas ou éticas levadas em conta ao decidirem pelo cumprimento ou pela transgressão de uma determinada regra, levando o observador à percepção de que a gincana pode ser explicada pela orientação de cada equipe para alcançar o payoff da vitória. A esta explicação ancorada no comportamento dos agentes deve ser somada uma dimensão "institucional", uma vez que, na gincana, o regimento importa.

Há quem veja a política - e a estude - como uma gincana. De fato, a mainstream da ciência política brasileira identifica-se prevalecentemente 
com essa alegoria. Trata-se de uma linhagem fortemente influenciada em suas bases mais remotas pelo conceito de poder e de Estado de Weber, para desembocar, contemporaneamente, em uma majoritária preferência pela corrente neoinstitucionalista, notadamente em sua versão da escolha racional ${ }^{8}$.

A política como gincana direciona o foco das pesquisas para aquilo que Weber definira como "a liderança, ou a influência sobre a liderança [...] de um Estado" (Weber, 2008, p. 55). A luta para controlar diretamente ou influenciar o Estado define esta forma alegórica. Partidos, grupos de interesses, classes, gêneros e etnias são exemplos de "equipes" que podem comparecer às abordagens. As regras do jogo interessam às investigações e adquirem especial relevo em estudos sobre temas como relações entre poderes, sistemas eleitorais e desenhos institucionais, por exemplo. Desde a descrição centrada no comportamento de agentes que querem conduzir o Estado - entendido, ao menos em alguma medida, como instrumento- a seu favor até as formulações normativas que apontam para o que entendem como formas estatais mais legítimas ou inclusivas, a competição para saber quem lidera ou influencia a liderança estatal é o cerne do tipo alegórico em comento. De algum modo, o que Katznelson e Milner (2002) entendem como ciência política tout court se identifica com a noção aqui apresentada para a ciência política como gincana ${ }^{9}$.

A política como gincana adota, com significativa frequência, os indivíduos como unidades preferenciais de análise, o modelo teleológico de ação como esquema explicativo da atuação dos agentes politicamente ativos e a dominação/coerção (Gewalt) como aspecto central ao conteúdo semântico da categoria poder.

Quanto às técnicas de pesquisa, as preferências costumam recair sobre estudos respaldados em evidências quantificáveis, com intenso emprego da estatística (a regressão logística é uma ferramenta especialmente prestigiada) e da coleta de dados empíricos primários mediante, por exemplo, surveys.

8 Sobre as versões do novo institucionalismo em ciência política, conferir Hall eTaylor (2003). Para uma abordagem específica do novo institucionalismo da escolha racional, conferir Weingast (2002).

9 Conferir a definição daquilo que, para os autores, unificaria as multiplicidades da disciplina: "uma orientação pragmática para o estado moderno que faz a análise do poder e da escolha um atributo constitutivo; atenção à natureza e à estabilidade dos regimes políticos liberais e, adicionalmente, à democracia; e uma dedicação ao estudo do Estado e da democracia liberal de formas que são transparentes e sistemáticas" (Katznelson e Milner, 2002, p. 2, tradução nossa). Note-se que o horizonte do modelo liberal de democracia não é ultrapassado nessa definição. 
Dentre inúmeros outros, destacam-se os potenciais desse campo para fins de compreensão da lógica parlamentar, caracterização de partidos, governos e sistemas político-eleitorais, descrição de movimentos táticos ou estratégicos dos atores internos ao campo político, produção intensa de dados primários e elaboração de prognósticos confiáveis de curto e médio alcances. Sem os trabalhos daqueles que entendem a política como a gincana do Estado liberal jamais seria possível compreender rigorosamente aspectos fundamentais das sociedades modernas. Os estudos de gênero não seriam os mesmos sem as pesquisas sobre a sub-representação feminina nos parlamentos. A compreensão de que secularização e modernização não correm em sincronia ou paralelismo histórico jamais ficaria tão clara sem os trabalhos que notaram a emergência de temas religiosos em processos eleitorais recentes. A influência de grandes corporações sobre as decisões de governo ficaria lacunosamente estudada sem os estudos empíricos de campaign finance e dos liames entre atração de investimentos, êxito eleitoral e redução de bases de arrecadação fiscal. Enfim, a profissionalização de cientistas dedicados à política como gincana permite a focalização do espectro cognitivo, com positivo impacto sobre o rigor e a clareza das conclusões obtidas.

Por outro lado, nota-se a insuficiência dessa maneira de se estudar a política no que tange à identificação da gênese das preferências, à naturalização do Estado liberal e à sua apreensão de modo instrumental ${ }^{10}$, à ênfase na democracia como um jogo eleitoral, à capacidade limitada de interpretação das crises de regime e à tendência ao insulamento epistêmico e metodológico da ciência política. Assim, há pesquisadores que, insatisfeitos com esses limites, direcionam o olhar sobre outros objetos, como indicam os tipos a seguir.

\section{A política como reunião de condomínio}

Síndicos de condomínios, em geral, esperam daqueles que habitam edifícios ou comunidades cercadas duas principais atitudes: pontualidade quanto ao pagamento das mensalidades e participação nas reuniões. O taxpayer passivo - que cuida dos respectivos afazeres privados, exerce abundantemente seu direito de não participar da gestão e dos espaços decisórios e, quando tem algum problema de ordem individual, endereça uma reclamação ao síndico - não costuma ser o sujeito mais apreciado por quem entende que a

10 Quanto ao caráter das noções instrumentais de Estado, conferir Bianchi (2007). 
vida da comunidade só se aprimora e se aperfeiçoa quando todos se engajam e contribuem para as questões comuns. A reunião é um espaço relevante não apenas porque legitima medidas como aumento de taxas e promoção de reformas, mas também porque nela cada um desenvolve habilidades argumentativas, conhece a perspectiva dos outros e passa a considerá-las (o vizinho de mau humor no elevador pode, na reunião, revelar-se uma nobre pessoa em um momento de dificuldade na vida profissional) antes de tomar decisões ou elaborar juízos morais. Nela se aprende ainda sobre as minudências da administração condominial e se desenvolvem laços comunitários que aprofundam as redes, os vínculos e a solidariedade. A eleição do síndico e o quotidiano administrativo são aspectos de menor relevância diante do espaço inclusivo em que todos, de modo igualitário (ressalvadas as limitações usualmente impostas a inquilinos, que, em todo caso, não são plenamente parte de "nós"), têm condições não apenas de se fazerem presentes, mas de constituírem naquele âmbito um sujeito novo e específico, entendido doravante como "nosso prédio", "esta comunidade" ou "o condomínio".

A política pode ser vista e estudada como uma reunião de condomínio. A constituição do "povo", a ênfase na soberania popular, o engajamento cívico - e ético - na construção coletiva do bem comum e os espaços de livre e ativa participação política franqueados aos cidadãos são os aspectos privilegiados por esse tipo de abordagem. A influência teórica mais clara desses estudos remete a Rousseau, seu conceito de vontade geral e sua crítica aos antepassados daqueles que hoje entendem a política como gincana (os liberais ingleses, por exemplo), formulada em constatações como a de que a ideia de liberdade por eles assumida ficaria restrita a um átimo que ocorreria apenas "durante a eleição dos membros do Parlamento" (Rousseau, 2002, p. 45). Na contemporaneidade, produções teóricas como as de Carole Pateman (1992) e estudos empíricos voltados a fóruns estatais abertos à sociedade civil, em relação aos quais, aliás, o Brasil se destaca (Avritzer, 2009, 2010) são exemplos desse modo de ver e fazer ciência política.

Em uma casca de noz, o objeto precípuo da política como reunião de condomínio é, em sua variante brasileira contemporânea, a participação social. Os cientistas que aderem a essa concepção identificam a política em âmbitos como assembleias de orçamentos participativos, conselhos gestores de políticas e conferências temáticas. Há, em medida similar, pesquisas de índole descritiva - com emprego de diferentes técnicas de pesquisa, sejam 
quantitativas ou qualitativas - e normativa. O cerne dos estudos, de qualquer modo, são os mecanismos de democracia participativa que permitem aos cidadãos direta ou mais próxima atuação nos processos decisórios públicos. Não segue dessa premissa que esta variante da ciência política seja indiferente à gincana para a liderança estatal e ainda menos às instituições.

De fato, os estudos enfocados na política como reunião de condomínio reconhecem e até discutem as outras variantes da ciência política brasileira nos dias atuais. Há, por exemplo, claras conexões entre esta vertente e os trabalhos de política como gincana nas publicações que aferem o impacto de conferências na produção legislativa (Pogrebinschi e Santos, 2011). Do mesmo modo, encontram-se estudos que conectam aquilo que adiante é chamado de política como "fogo no pneu" com a reunião de condomínio, a exemplo de um rigoroso trabalho em que se associa mobilização social com as dinâmicas de conselhos de políticas públicas (Coelho et al., 2010). Ainda mais comuns são os estudos que aproximam o objeto da próxima subseção - a política como cafeteria - da variante aqui em comento. Um influente livro publicado na primeira década do século XXI exemplifica, já em seu título, Participação e deliberação", como é usual essa aproximação no Brasil (Coelho e Nobre, 2004).

São frequentes, de qualquer modo, as produções que conferem ênfase à gincana estatal como limitada e pretendem radicalizar a participação social, a ponto de levar Estado e sociedade a convergirem, de modo a germinar, nos termos de Boaventura Santos (2006), o grande condomínio do "Estado como novíssimo movimento social”. Essa tese se ancora em um diagnóstico crítico em relação à política como gincana, assim formulado: “a fragilização da obrigação política vertical entre Estado e cidadão faz com que ela não possa garantir, só por si, a realização dos valores, a qual [...] foi suficiente para garantir a legitimidade mínima do Estado" (Santos, 2006, p. 366) ${ }^{11}$.

Os estudos de política como reunião de condomínio ostentam, entre os seus incontáveis méritos, os seguintes atributos: 1) permitem a identificação da gênese das preferências políticas, antes de tomá-las como dados a priori, como é comum entre os que enxergam a política como gincana; 2 ) ampliam

11 O autor é um intelectual português que, para construir sua teoria da democracia participativa, refere-se centralmente à experiência brasileira. Ademais, o artigo em que delineia o seu entendimento sobre a democracia é redigido em coautoria com um cientista político brasileiro, Leonardo Avritzer (Santos e Avritzer, 2002). 
o espectro cognitivo da ciência política, de modo a permitirem a elaboração de juízos críticos ou de contribuições normativas que irrompam para além das insuficiências da democracia liberal; 3) guardam maior correspondência descritiva e realista diante das "novas formas de procedimentalismo participativista que emergiram nos países do Sul” (Santos e Avritzer, 2002, p. 45).

Há, contudo, limites quanto à concepção em questão. Semelhantemente à versão da política como gincana, continua a tomar-se o Estado como parâmetro, ainda que o foco sejam os seus fóruns participativos. Essa escolha implica, de um lado, o risco da miopia para "processos comunicativos" de "cunho político" que "dependem de recursos do universo vital", os quais "se formam de maneira espontânea" ou "só podem ser atingidos com grande dificuldade caso o caminho escolhido para se tentar alcançá-los seja o do direcionamento político" (Habermas, 2002, p. 284); de outro lado, a dificuldade em entender eventos ou jornadas antiestatais que não almejam maior inclusão nos mecanismos decisórios do Estado, mas, ao contrário, os têm como objeto de refutação (Young, 2001). Há, em busca de superação dessas limitações, quem opte por concentrar-se em outras duas formas alegóricas. Uma delas é a cafeteria, discutida a seguir.

\section{A política como cafeteria}

Nos séculos XVI e XVII o Império Otomano abrigou espaços onde os distintos estratos da sociedade islâmica se misturavam e, consumindo café, davam-se a interlocuções livres acerca de temas como literatura, entretenimento e política. Os sujeitos privados encontravam-se em um espaço público, no qual as pessoas podiam interagir sob um marco igualitário não observado, normalmente, para além dos limites daquelas casas dedicadas ao consumo de café. Como nota um recente trabalho sobre a esfera pública otomana, "o ato de compartilhar uma xícara de café colocava de lado os rótulos sociais para se compartilhar, temporariamente, pequenos momentos de esclarecimento e generoso contentamento" (Collaco, 2011, p. 62, tradução nossa).

Eurocêntrica como sói, a filosofia política do Ocidente, mesmo em variante autodeclarada crítica, identifica cerca de duzentos anos depois, já em solo europeu, uma prática semelhante àquela que nascera no Império Otomano. Assim, reportando-se principalmente às cafeterias londrinas do século XIX (ladeadas pelos salões parisienses e sociedades de comensais alemãs), Habermas (2003, p. 42) nota a emergência de uma "esfera das pessoas privadas 
reunidas em um público". A prática de intercâmbio argumentativo em que pessoas racionais emitem discursos segundo um ambiente destituído de coerção e orientadas à validação dos atos de fala, com base no triplo critério da verdade/eficiência, da sinceridade do falante e da correção normativa, inspira o modo como inúmeros cientistas políticos dos dias atuais concebem o respectivo objeto. Há, com efeito, quem veja a política com o olhar de quem observa as interações ocorrentes nas cafeterias.

Estudar a política como uma cafeteria implica a atribuição de ênfase aos processos discursivos informais, que carreiam do espaço público não estatal para o sistema do Estado fluxos de opiniões aptos a influenciarem e conferirem ou subtraírem legitimidade às decisões exaradas pela burocracia. A opinião pública, a circulação das ideias no tecido social e os espaços temáticos não estatais de debate ou interlocução sobre problemas políticos são, em geral, os objetos preferidos pela vertente em questão.

Nota-se, entre os que concebem a política como cafeteria, um significativo ecletismo, manifestado em múltiplas ordens. Primeiramente, quanto ao objeto estudado, não são incomuns os trabalhos que enfocam, concomitantemente, reuniões de condomínio e cafeterias, ou a possibilidade de se fazer das reuniões um espaço homólogo ao das casas de café. Hibridismos entre gincana e cafeteria são menos comuns, mas ocorrem, em especial nos trabalhos que se interessam por outcomes das conversas no café em termos de organização de equipes ou resultados da gincana. No que tange aos tipos de investigação científica, há trabalhos ensaísticos, teóricos e empíricos, de tal arte que esta não é uma distinção significativa deste tipo alegórico. Quanto às técnicas de pesquisa, encontram-se estudos estribados em análises de conteúdo (usualmente quando se pretende entender os fluxos comunicativos em meios de comunicação), análises de redes sociais (atualmente, com o emprego de softwares específicos ou mesmo de linguagens de programação, a exemplo do R), grupos focais, surveys e, em menor medida, investigações participantes.

Conceber a política como cafeteria é uma opção fecunda e revestida de ímpar potencial para o avanço deste campo acadêmico. Antes de tudo, amplia-se o olhar sobre os pontos cegos que usualmente ocorrem quando a ciência se circunscreve aos limites da gincana ou da reunião de condomínio. Construções teóricas como "democracia do público" (Manin, 1995), elementos fáticos como a influência do livre debate sobre o sistema estatal e 
ferramentas metodológicas como o índice de qualidade discursiva (Steenberg et al., 2003) são apenas alguns exemplos dos acréscimos ensejados por essa maneira de se estudar o poder. A teia linguística que delimita as fronteiras do universo de possibilidades das decisões políticas, os liames entre sociedade civil e Estado, as formas de ação política que exorbitam o arranjo partido-parlamento-sindicato, outrora hegemônico nos trabalhos acadêmicos, e a própria relação entre mercado, cultura e Estado se elevam a um patamar superior quando o objeto do estudioso de ciência política se subsume à alegoria da cafeteria.

Há, como nos outros tipos abordados, lacunas e limites que remanescem quando a política como cafeteria é somada aos outros dois tipos até aqui discutidos. $\mathrm{O}$ fato é que se presume, na cafeteria, uma igualdade pouco crível em sociedades marcadas por práticas de dominação associadas a elementos como gênero, raça e classe. Ademais, mantém-se, como na gincana e na reunião de condomínio, a ideia de que o Estado é um horizonte inultrapassável, uma vez que a informalidade da opinião pública deságua, em algum momento, no questionamento ou na subtração apenas circunstancial de legitimidade das decisões estatais. A sublevação orientada à derrocada ou superação do Estado, todavia, não comparece aos trabalhos que vislumbram a política como cafeteria. Em suma, trata-se de uma maneira de se apreciar a política que, em suas inúmeras e frequentemente autocríticas manifestações, não leva as desigualdades e conflitos sociais às últimas consequências. Na cafeteria, além de jurisconsortes livres e iguais, há moças trabalhando uniformizadas no balcão, policiais à paisana observando a conversa de opositores, senhores desempregados encabulados com os preços do cardápio e um distinto homem branco atrás da máquina registradora, que recebe com fidalguia e presteza apenas quem pode lhe pagar. Além daquelas paredes, comparece um mundo ainda mais complexo e repleto em clivagens que não podem ser superadas por meio de uma prática discursiva. Os estudos de ciência política vinculados à alegoria em comento não costumam revelar-se aptos a responderem à denúncia marcusiana de que a inclusão de discursos pode encerrar apenas uma "tolerância repressiva"12, de

12 "Sob um sistema constitucionalmente garantido e (geralmente e também sem muitas e claras exceções) praticado, são toleradas liberdades e direitos civis, a oposição e a dissensão, a menos que elas propaguem a violência e/ou a exortação para a organização da subversão violenta. A hipótese 
modo que a estratégica e incondescendente prática de resistência social não institucionalizada não se afigura apenas como uma anomalia na política, mas, ao contrário, pode ser vislumbrada como sua componente quintessencial. O subsequente e derradeiro tipo apresentado pretende lidar com esses problemas.

\section{A política como fogo no pneu}

Um clichê que unifica continentais e anglófonos no estudo da ciência política reside em buscar na Florença renascentista, em especial na idiossincrática variante de humanismo cívico inscrita no pensamento de Maquiavel, as fontes de uma compreensão realista do objeto, supostamente depurada de uma dissolução ou redução das coisas do poder em questões de eticidade e, assim, concentrada na estabilidade, tão bem insculpida na expressão mantenere lo stato. Desde os recentes trabalhos orientados pela vertente teorética do contextualismo socio-histórico (Wood, 2012), até as exegeses que produzem mirabolantes argumentos ancorados em diacronismos entre os aconselhamentos dedicados a Lorenzo de Médici e à conjuntura política da semana, Maquiavel é onipresente na ciência política ou, ao menos, nos estudos propedêuticos desta disciplina. É certo que a obra do florentino não recebe apreço e destaque uniformes em todas as suas passagens ou momentos. O Capítulo $4^{\circ}$ do Livro Primeiro dos Discorsi, por exemplo, não é associado à gênese da ciência política moderna com a mesma frequência ocorrente em relação a passagens como os trechos de $O$ príncipe que apontam para a necessidade das boas armas, ou que recomendam a priorização da realidade do que se faz, em detrimento da abstração normativa do que se deve fazer, de modo a se evitar a ruína (Maquiavel, 1996). É, precisamente, naquela pouco discutida passagem dos Discorsi que Maquiavel exalta o tumulto, a desunião entre povo e aristocracia, a desordem, os gritos e rumores como causas da liberdade de Roma (Maquiavel, 1994).

subjacente é de que a sociedade estabelecida é livre, e que nenhum aprimoramento, até mesmo uma mudança na estrutura e nos valores sociais, ocorreria no curso normal dos eventos, preparados, definidos e testados na discussão livre e igualitária, na feira aberta de ideias e bens. [... J Justamente por isso, essas minorias que se esforçam por uma mudança do todo propriamente dito, sob ótimas condições que raramente prevalecem, serão deixadas livres para deliberar e discutir, para falar e reunir-se - e serão deixadas inofensivas e desamparadas diante da maioria subjugadora que milita contra a mudança social qualitativa. Essa maioria é firmemente fundamentada na crescente satisfação das necessidades e da coordenação mental - e tecnológica - a qual testemunha o desamparo geral de grupos radicais em um sistema social que funciona - bem" (Marcuse, 2007, p. 37-8). 
Há, com efeito, na esteira do Capítulo $4^{\circ}$ do Primeiro Livro dos Discorsi, quem veja a política como um embate antagonístico e, frequentemente, irremediável entre dominadores e dominados. O teatro de operações dessas lutas, em última instância, não está em ambientes palacianos, fóruns participativos ou interações informais, mas nas barricadas em que pneus ardem e vozes usualmente silenciadas emergem. No tipo alegórico em questão, a política se explica e se realiza nas lutas sociais.

Assim, o estado de direito é, antes de uma charneira que liga o mundo da vida ao sistema, de uma regra do jogo em que interesses individuais competem ou, ainda, de um marco fundador em que "nós, o povo", nos constituímos, a resultante de reis decapitados, prisões derrubadas, praças tomadas por multidões e toda sorte de agitação insurgente.

O sistema eleitoral é menos lembrado pelas regras de financiamento de campanha ou pelos parâmetros para transformação de votos em cadeiras no Parlamento do que é entendido como produto de movimentos como as “Diretas Já!” brasileiras ou a Revolução dos Cravos lusitana.

Ao pensar em igualdade racial e seus aspectos políticos, os praticantes dessa maneira de se fazer ciência política tendem a se concentrar sobre movimentos como os Panteras Negras, em detrimento das oscilações na produção normativa do Congresso ou na hermenêutica constitucional da Suprema Corte.

Quando o assunto é a regulação dos mercados por meios políticos, as pesquisas se interessam por greves, organizações socialistas e boicotes, antes de temas como o lobby parlamentar favorável a ajustes fiscais ou oscilações das votações conferidas a partidos trabalhistas.

Do mesmo modo, um tema como participação das mulheres na política é estudado sob o prisma de protestos como a Marcha das Vadias, em oposição a opções científicas dedicadas ao cômputo da presença feminina em legislativos.

Enfim, a política como fogo no pneu se dedica a protestos, sublevações, insurgências, revoluções e toda prática de agonismo político que, antes de se processar por canais institucionais, tende a rechaçar as próprias instituições, parcial ou totalmente, em sua existência e legitimidade. A política como fogo no pneu não reduz o seu objeto à categoria "movimentos sociais", por duas razões. Primeiramente, a prática de movimentos como membros de conselhos gestores ou atores do terceiro setor da economia, em um 
contexto de confluência perversa (Dagnino, 2004) no qual a desregulação neoliberal coincide com a emergência de maior organização da sociedade civil brasileira, não se encaixa nesse tipo. Em segundo lugar, eventos como distúrbios e levantes (riots) que não se enquadram necessariamente como movimentos sociais (Simiti, 2011) integram o tipo alegórico da política como fogo no pneu. Incorporam-se à ideia, portanto, práticas que miram o Estado como alvo a ser derrotado plena ou parcialmente, em vez de espaço para o exercício de influência ou participação nos respectivos negócios, além de condutas que, ao arrepio dos manuais de protestos lícitos próprios às normas de direito penal ou constitucional, atuam contra empresas, proprietários de imóveis rurais ou urbanos, concessionários de serviços públicos etc ${ }^{13}$

É lícito supor que os estudos de política como fogo no pneu sejam, dentre os quatro tipos alegóricos apresentados, os mais ecléticos e diversos metodológica e teoricamente. As opções, no que tange aos tipos de pesquisa científica adotados e às correspondentes técnicas de coleta ou análise dos dados, são tão vastas quanto o repertório das ciências sociais contemporâneas. Um evento como as Jornadas de Junho de 2013 no Brasil, por exemplo, foi estudado com base em análise de redes sociais por meio de softwares apropriados (Pimentel e Silveira, 2013), entrevistas semiestruturadas (Sarmento et al., 2015) e pesquisa participante (Tavares e Roriz, 2015). Esse ecletismo também se manifesta sob o aspecto teórico. Há trabalhos dedicados ao entendimento político dos protestos e lutas sociais que se referenciam em um amplíssimo leque de perspectivas, desde o marxismo à escolha racional.

O potencial do estudo da política como fogo no pneu é ímpar. Pesquisadores dedicados a protestos e movimentos com baixa aceitação às

13 A formulação teórica mais próxima da ideia de política como fogo no pneu se encontra na categoria "contentious politics" (política contenciosa) tal como apresentada por McAdam, Tilly eTarrow no clássico Dynamics of contention: "interação episódica, pública e coletiva entre os autores de reivindicações e seus objetos quando (a) pelo menos um governo for autor, objeto ou uma parte nas reivindicações e (b) as reivindicações, se realizadas, afetarem os interesses de pelo menos um dos autores das reivindicações" (McAdam, Tilly e Tarrow, 2004, p. 5). As categorias não são idênticas, todavia, porque a política como fogo no pneu não contempla o Estado como sujeito ativo de reivindicações. Ademais, um protesto contra uma grande mineradora privada que obstrui uma de suas linhas férreas ou a ocupação de uma fazenda de laranjas voltadas ao mercado exterior - práticas de confronto que nem sempre têm o Estado sequer como mediador - se incluem no presente tipo alegórico, mas escapam à definição supracitada. 
instituições conseguem antever realidades políticas que, usualmente, ingressam tardiamente no radar de quem estuda gincana, reunião de condomínio ou cafeteria. Apenas este tipo alegórico é capaz de explicar a um institucionalista fenômenos como a emergência eleitoral do Syriza, na Grécia, ou do Podemos, na Espanha. Eventos como a ocupação da praça Tahrir, no Egito, da praça Taksin, na Turquia, a Revolta dos Pinguins, no Chile, o Junho brasileiro, o $14 \mathrm{~N}$, do sul da Europa, a greve dos mineiros na Espanha e o Occupy Wall Street, em Nova York, são centrais na paisagem política do mundo contemporâneo e revestem-se de potencial explicativo e preditivo para todas as esferas do poder, inobstante o grau de institucionalização.

Em síntese, o estudo de ciência política que acredita ser possível delegar à sociologia ou áreas afins a compreensão de lutas e protestos sociais deve se conformar com uma atrofia do respectivo espectro cognitivo, que macula até as mais ortodoxas áreas da disciplina, como o estudo de partidos políticos ou de comportamento eleitoral.

Há, contudo, insuficiências na concepção de política como fogo no pneu. Primeiramente, nota-se que, apesar da profusão de opções metodológicas adotadas, a natureza evanescente dos objetos perquiridos e a escassa produção de pesquisa voltada a métodos que atendam às suas peculiaridades ${ }^{14}$ tendem a comprometer o fôlego generalizante ou mesmo a qualidade das comparações empreendidas. Ademais, o entendimento da política como fogo no pneu tende a conceber as instituições e seus meandros a partir de um olhar muito distante que, por um lado, permite uma compreensão científico-social ampla, mas, por outro, favorece reducionismos que implicam uma leitura do Estado, do direito, das políticas públicas, dos partidos políticos viáveis eleitoralmente e de toda uma gama de objetos relevantes para a ciência política desprovida de uma imersão mais detida em suas nuances e nas notáveis diferenças entre as suas manifestações no tempo e no espaço.

A apresentação dos tipos alegóricos aqui delineada parece respaldar a formulação de duas premissas: 1) o emprego de alegorias permite um olhar diferente sobre a ciência política, agregando perspectivas e incrementando

14 Uma importante exceção é a recente obra Methodological practices in social movements research (Della Porta, 2014). Apesar do título sugerir uma restrição do objeto, há capítulos, como o 13 e o 14, em que protestos, antes de movimentos sociais, são o foco da discussão metodológica. 
a compreensão que a disciplina guarda a seu próprio respeito, porquanto atravesse fronteiras entre subdisciplinas e tradições teóricas, permitindo uma classificação dos objetos estudados que, em grande medida, condiz com as fronteiras entre grupos de afinidade e equipes de pesquisa que definem o campo no Brasil; 2) os objetos associados a cada um dos tipos alegóricos apresentados guardam intrínseca dignidade epistêmica, de modo que são imprescindíveis na composição de uma ciência dedicada à compreensão da relação social de poder. Segue dessa segunda premissa que a dispersão dos tipos alegóricos em meio à produção acadêmica na ciência política brasileira deve ser relativamente equilibrada, de tal maneira que todos estejam representados em medida quase equivalente nos artigos publicados. Isto é o que se afere na seção seguinte.

\section{Um mapa tipológico-alegórico da ciência política brasileira}

As seções anteriores, no contexto da proposição de uma tipologia alegórica, argumentaram em favor de duas premissas epistêmicas e teoréticas quanto à ciência política: 1) a relação social do poder é polissêmica, e é desejável que a ciência política dê conta, tanto quanto possível, de sua amplitude semântica na definição do seu objeto específico; 2) os quatro tipos alegóricos apresentados encerram virtudes e insuficiências ímpares, do que se conclui que uma ciência política abrangente e digna das complexas relações sociais hodiernas deveria incorporá-los em grau de relativo equilíbrio. Este não parece ser o cenário, porém, da ciência política brasileira. A aferição bibliográfica a seguir indica um claro viés em favor da concepção de ciência política como gincana na produção disciplinar do país.

O levantamento concentrou-se em periódicos científicos em detrimento de livros, teses, dissertações e outras fontes. Essa opção se justifica no relativo consenso de que a ciência política brasileira concentra expressiva parcela de sua produção e de seu debate acadêmico em revistas especializadas, nas quais, ademais, dados e argumentos consignados em dissertações, teses, anais de eventos e livros tendem a se discutir ou projetar.

O conjunto eleito no universo de periódicos científicos brasileiros compôs-se das revistas editadas por entidades acadêmicas de ciências sociais (departamentos, programas de pós-graduação, associações científicas etc.). Esse critério garantiu que periódicos de outras áreas do saber, como 
saúde pública e administração de empresas, em que há incidental presença de trabalhos de ciência política, não fossem acrescentados à amostra. Optou-se, ainda, por cingir-se aos periódicos classificados pela autarquia federal Capes nos estratos A1 e A2 da área de Ciência Política e Relações Internacionais. Esse critério se ancora em duas razões complementares: 1) em geral, cientistas políticos mais influentes e engajados no campo tendem a priorizar a remessa de suas produções acadêmicas para revistas classificadas no estrato A, em função das vantagens relativas que a publicação nesses periódicos implica para a avaliação dos programas de pós-graduação a que estão vinculados e, por via oblíqua, para as respectivas carreiras; 2) a Capes conta com um robusto sistema de classificação de periódicos, pautado por juízos de pares e critérios suficientemente objetivos, inscritos em um texto denominado "documento de área", tão amplamente aceito que não seria recomendável, aqui, formular um mecanismo classificador alternativo ou concorrente. As revistas escrutinadas, portanto, foram as seguintes: Dados (Iesp/Uerj), Opinião Pública (Cesop/Unicamp), Revista Brasileira de Ciências Sociais (Anpocs), Brazilian Political Science Review (ABCP), Estudos Avançados (IEA/USP), Lua Nova (Cedec) e Revista de Sociologia e Política (UFPR).

O período compreendido delimitou-se entre 2007 e 2013. Esse intervalo não é exaustivo, mas se revela suficiente como amostra do momento contemporâneo da ciência política brasileira, captando instantes relevantes, como o salto na pós-graduação e no impacto internacional da produção científica.

Em complementação aos critérios enunciados, a amostra foi restrita a trabalhos em que ao menos um dos autores estivesse vinculado, como discente ou docente, a programas de pós-graduação ou unidades acadêmicas (departamentos, institutos, faculdades etc.) de ciência política. Não foram considerados, assim, doutores em ciência política que trabalham exclusivamente em outros departamentos (como de economia, direito ou sociologia). Quando o departamento é amplo e abarca mais de uma ciência (por exemplo, Departamento de Sociologia e Ciência Política da Universidade Federal de Santa Catarina) foi considerada a área de atuação do professor disponibilizada no site da instituição. Quando essa informação não estava disponível ou não foi encontrada, considerou-se o doutorado do professor como critério. No caso de doutores em "ciências sociais", perscrutou-se a 
"área" e a "subárea" declaradas pelo pesquisador no currículo da Plataforma Lattes. A necessidade de chegar a tal ponto para aferir a área da profissional ou do profissional foi, de qualquer modo, rara. Foram incluídos, outrossim, profissionais da ciência política que trabalham em instituições e associações não acadêmicas, mas políticas, tais como Câmara dos Deputados, think tanks, fundações partidárias, organizações não governamentais, Senado, gabinetes, movimentos sociais etc. Enfim, não foram considerados artigos estrangeiros de ciência política, assim entendidos como os de autoria de pesquisadores - inobstante a nacionalidade - com vinculação principal a instituições estrangeiras. Este foi um modo de se restringir, assumidos os riscos de incompletude, a categoria "ciência política brasileira".

Com essa base, adotou-se a técnica de pesquisa atinente à análise de conteúdo estribada, prima facie, nos resumos e palavras-chave dos artigos, complementados, sempre que necessário, por uma perquirição minudente do inteiro teor textual.

A apuração bibliográfica efetivada limitou-se a trabalhos empíricos ou factuais. Em outros termos, foram apreciados apenas os artigos que se dedicaram à compreensão da relação social do poder no mundo fenomênico. Desse modo, textos de filosofia, epistemologia, metodologia e história das ideias ou intelectual em política foram remetidos para uma quinta categoria.

Uma vez que os tipos alegóricos aqui propostos não encerram uma taxonomia, houve dois casos anômalos, de artigos irredutíveis à tipologia proposta, que se enquadraram, concomitantemente, em três categorias. Trata-se de trabalhos dedicados à aferição, sob igual relevância, de condutas oscilantes de participação em partidos políticos à adesão a passeatas e boicotes.

Todo o processo de busca, organização e interpretação dos dados foi registrado para avaliação dos pares quanto à sua validade metodológica, replicabilidade e pertinência científica ${ }^{15}$.

Os resultados obtidos expressam-se nas tabelas 1, 2 e 3, que correspondem respectivamente aos periódicos dos estratos $\mathrm{A} 1$ e $\mathrm{A} 2 \mathrm{e}$ à totalidade da amostra.

15 A base de dados acostada às glosas com critérios e avaliações se encontra disponível para acesso aberto em www.4shared.com/folder/rpEvXpCF/BASE_DE_DADOS.html. 
Tabela 1 - Distribuição dos tipos alegóricos em periódicos classificados como A1 (somente artigos considerados na análise)

\begin{tabular}{c|c|c|c|c|c|c}
\hline Tipologia & $\begin{array}{c}\text { História } \\
\text { da } \\
\text { CP/teoria } \\
\text { política }\end{array}$ & $\begin{array}{c}\text { Fogo } \\
\text { no } \\
\text { pneu }\end{array}$ & $\begin{array}{c}\text { Reunião } \\
\text { de } \\
\text { condomínio }\end{array}$ & Cafeteria & Gincana & $\begin{array}{c}\text { Total de } \\
\text { artigos de CP } \\
\text { por revista } \\
(2007-2013)\end{array}$ \\
\hline Dados & $\begin{array}{c}14 \\
(16,6 \%)\end{array}$ & $\begin{array}{c}2 \\
(2,4 \%)\end{array}$ & $\begin{array}{c}4 \\
(4,8 \%)\end{array}$ & $\begin{array}{c}8 \\
(9,5 \%)\end{array}$ & $\begin{array}{c}56 \\
(66,7 \%)\end{array}$ & $\begin{array}{c}84 \\
(100 \%)\end{array}$ \\
\hline Opinião & 6 & 3 & 5 & 24 & 50 & 86 \\
Rública* & $(7,0 \%)$ & $(3,5 \%)$ & $(5,8 \%)$ & $(27,9 \%)$ & $(58,1 \%)$ & $(100 \%)$ \\
\hline Total (\%) & 19 & $\begin{array}{c}1 \\
(36,5 \%)\end{array}$ & $\begin{array}{c}1,9 \%) \\
(1,9 \%)\end{array}$ & $\begin{array}{c}2 \\
(3,8 \%)\end{array}$ & $\begin{array}{c}29 \\
(55,8 \%)\end{array}$ & $\begin{array}{c}52 \\
(100 \%)\end{array}$ \\
\hline
\end{tabular}

* Nessa revista em particular, percebe-se um número maior de artigos nas classificações do que no número total. Isso se deu por conta do artigo "Participação e pós-materialismo na América Latina”, de Ednaldo Ribeiro e Julian Borba, presente no v. 16, n. 1, de 2010.0 artigo, na sua classificação de "participação política", aborda desde 0 ingresso em partidos e 0 interesse por eleições até a atuação em protestos, passando ainda pela filiação em organizações trabalhistas etc. Portanto, julgamos inapropriado alocá-lo em uma única categoria. Se as porcentagens das colunas forem somadas, passarão de $100 \%$ justamente por causa desse artigo, que é de fato um, mas que foi computado em três colunas.

Gráfico 1 - Oscilação temporal da distribuição dos tipos alegóricos em periódicos classificados como A1

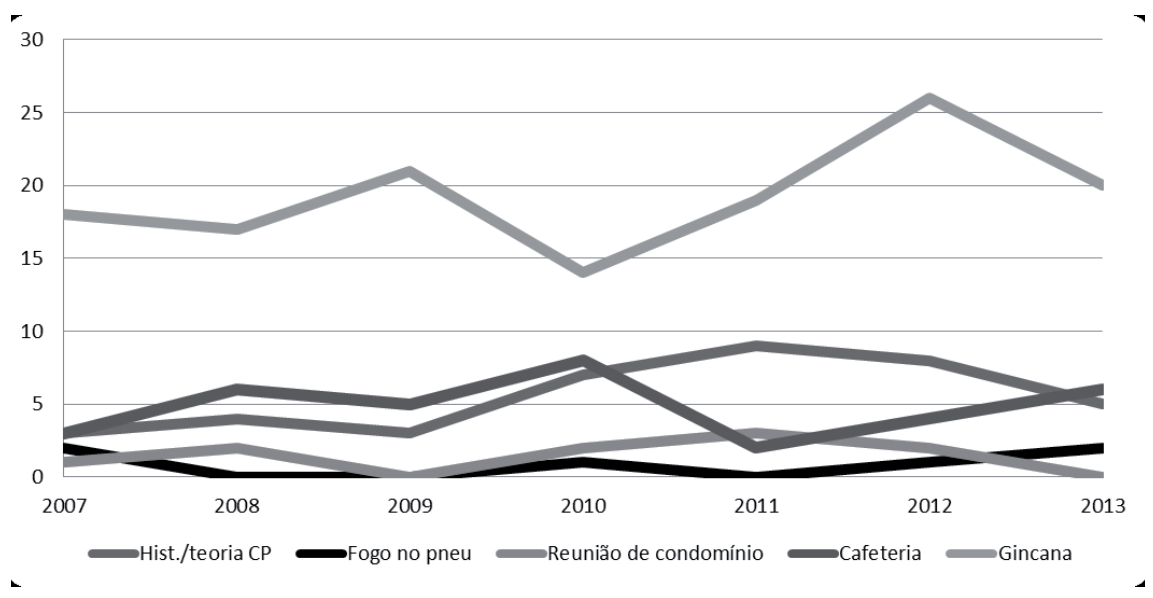


Tabela 2 - Distribuição dos tipos alegóricos em periódicos classificados como A2

\begin{tabular}{c|c|c|c|c|c|c}
\hline Tipologia & $\begin{array}{c}\text { História } \\
\text { da } \\
\text { (P/teoria } \\
\text { política }\end{array}$ & $\begin{array}{c}\text { Fogo } \\
\text { no } \\
\text { pneu }\end{array}$ & $\begin{array}{c}\text { Reunião } \\
\text { de } \\
\text { condomínio }\end{array}$ & Cafeteria & Gincana & $\begin{array}{c}\text { Total de } \\
\text { artigos por } \\
\text { revista } \\
(2007-2013)\end{array}$ \\
\hline Lua Nova & $\begin{array}{c}29 \\
(50 \%)\end{array}$ & $\begin{array}{c}5 \\
(8,6 \%)\end{array}$ & $\begin{array}{c}9 \\
(15,5 \%)\end{array}$ & $\begin{array}{c}2 \\
(3,4 \%)\end{array}$ & $\begin{array}{c}17 \\
(29,3 \%)\end{array}$ & $\begin{array}{c}58 \\
(100 \%)\end{array}$ \\
\hline BPSR & $\begin{array}{c}1 \\
(19 \%)\end{array}$ & $\begin{array}{c}1 \\
(2,4 \%)\end{array}$ & $\begin{array}{c}(2,4 \%) \\
(7,1 \%)\end{array}$ & $\begin{array}{c}29 \\
(69 \%)\end{array}$ & $\begin{array}{c}40 \\
(100 \%)\end{array}$ \\
\hline Estudos & $\begin{array}{c}33 \\
(30,8 \%)\end{array}$ & $\begin{array}{c}0 \\
(0 \%)\end{array}$ & $\begin{array}{c}10 \\
(9,3 \%)\end{array}$ & $\begin{array}{c}8 \\
(7,5 \%)\end{array}$ & $\begin{array}{c}56 \\
(52,3 \%)\end{array}$ & $\begin{array}{c}107 \\
(100 \%)\end{array}$ \\
\hline Avançados & $(16,7 \%)$ & $(0 \%)$ & $\begin{array}{c}0 \\
(0 \%)\end{array}$ & $\begin{array}{c}0 \\
(0 \%)\end{array}$ & $\begin{array}{c}5 \\
(83,3 \%)\end{array}$ & $\begin{array}{c}6 \\
(100 \%)\end{array}$ \\
\hline Total (\%) & $\begin{array}{c}71 \\
(33,6 \%)\end{array}$ & $\begin{array}{c}6 \\
(2,8 \%)\end{array}$ & $\begin{array}{c}20 \\
(9,5 \%)\end{array}$ & $\begin{array}{c}13 \\
(6,7 \%)\end{array}$ & $\begin{array}{c}107 \\
(50,7 \%)\end{array}$ & $\begin{array}{c}211 \\
(100 \%)\end{array}$ \\
\hline
\end{tabular}

* Novamente, perceber-se-á uma ligeira diferença entre a soma do percentual das colunas e os $100 \%$ do número total de artigos decorrente de dois artigos na revista Lua Nova e um na BPSR que foram alocados em mais de uma categoria.

Gráfico 2 - Oscilação temporal da distribuição dos tipos alegóricos em periódicos classificados como A2

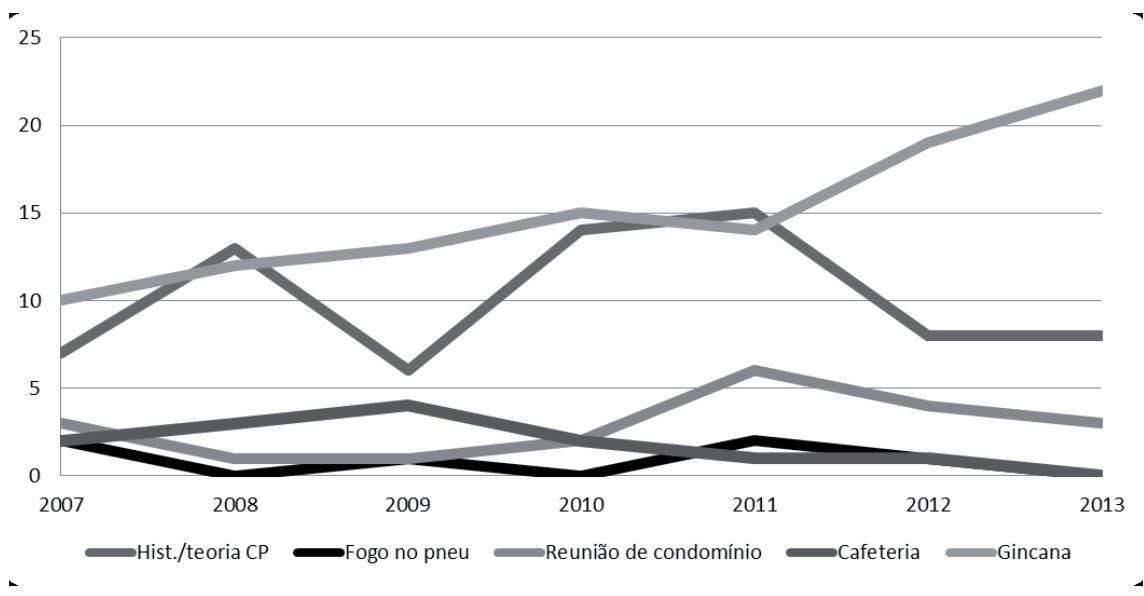


Tabela 3 - Distribuição dos tipos alegóricos em periódicos classificados como A (A1 + A2)

\begin{tabular}{c|c|c|c|c|c|c}
\hline Tipologia & $\begin{array}{c}\text { História } \\
\text { da } \\
\text { CP/teoria } \\
\text { política }\end{array}$ & $\begin{array}{c}\text { Fogo } \\
\text { no } \\
\text { pneu }\end{array}$ & $\begin{array}{c}\text { Reunião } \\
\text { de } \\
\text { condomínio }\end{array}$ & Cafeteria & Gincana & $\begin{array}{c}\text { Total de } \\
\text { artigos } \\
\text { por revista } \\
(2007-2013)\end{array}$ \\
\hline Periódicos A1 & $\begin{array}{c}39 \\
(17,6 \%)\end{array}$ & $\begin{array}{c}6 \\
(2,7 \%)\end{array}$ & $\begin{array}{c}10 \\
(4,5 \%)\end{array}$ & $\begin{array}{c}34 \\
(15,3 \%)\end{array}$ & $\begin{array}{c}135 \\
(60,8 \%)\end{array}$ & $\begin{array}{c}222 \\
(100 \%)\end{array}$ \\
\hline Periódicos A2 & $\begin{array}{c}71 \\
(33,6 \%)\end{array}$ & $\begin{array}{c}6 \\
(2,8 \%)\end{array}$ & $\begin{array}{c}20 \\
(9,5 \%)\end{array}$ & $\begin{array}{c}13 \\
(6,2 \%)\end{array}$ & $\begin{array}{c}107 \\
(50,7 \%)\end{array}$ & $\begin{array}{c}211 \\
(100 \%)\end{array}$ \\
\hline Total (\%)* & $\begin{array}{c}110 \\
(25,4 \%)\end{array}$ & $\begin{array}{c}12 \\
(2,8 \%)\end{array}$ & $\begin{array}{c}30 \\
(6,9 \%)\end{array}$ & $\begin{array}{c}47 \\
(10,8 \%)\end{array}$ & $\begin{array}{c}242 \\
(55,9 \%)\end{array}$ & $\begin{array}{c}433 \\
(100 \%)\end{array}$ \\
\hline
\end{tabular}

* Novamente, perceber-se-á uma ligeira diferença entre a soma do percentual das colunas e os 100\% do número total de artigos decorrente de dois artigos na revista Lua Nova e um na BPSR (A2) e de um artigo da Opinião Pública (Al) que foram alocados em mais de uma categoria.

Gráfico 3 - Oscilação temporal da distribuição dos tipos alegóricos em periódicos classificados como A (A1 + A2)

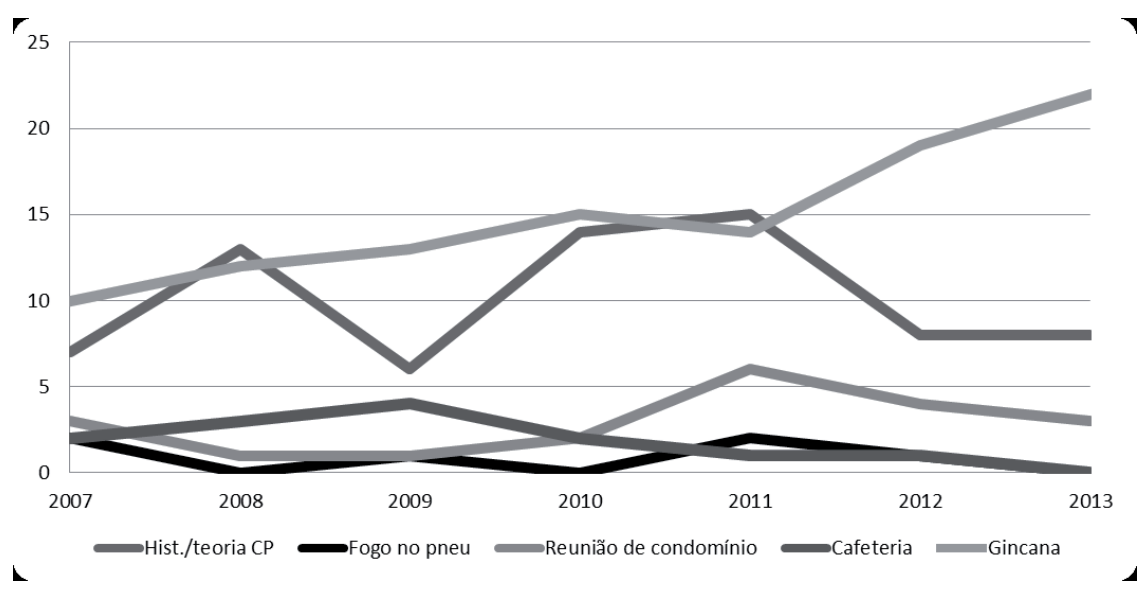

Nota-se que a visão de política como gincana prevalece fartamente. Chama a atenção, outrossim, que os estudos mais negligenciados sejam os que se enquadram no tipo alegórico do fogo no pneu. Nota-se também que, ao longo do período eleito para a composição dos dados apresentados, a preva- 
lência de publicações associadas à gincana e a frequência inferior dos artigos dedicados ao objeto fogo no pneu foram constantes. O período de notável expansão quantitativa e de consolidação institucional da ciência política no Brasil não correspondeu, com efeito, a uma distribuição mais uniforme das publicações entre as diferentes manifestações sociais da relação de poder. Esse cenário compromete a completude e solidez epistêmica da disciplina, conforme se discute na seção conclusiva deste artigo.

A reflexão teórica apresentada na seção anterior, à luz dos dados aqui apresentados, conduz à percepção de que o autoentendimento da ciência política brasileira muito tem avançado, mas ainda encontra espaço para complementações. A reduzida proporção de estudos enquadrados nas alegorias da cafeteria, da reunião de condomínio e do fogo no pneu compromete a qualidade da ciência política brasileira. Nos parágrafos seguintes explica-se esse argumento por meio de uma análise centrada no tipo alegórico cuja frequência observada foi a menor, equivalente a menos da metade de ocorrências em relação ao terceiro mais encontrado.

Quanto ao tipo menos representado, o fogo no pneu, nota-se que sua omissão é problemática por duas razões: 1) o fogo no pneu está umbilical e inelutavelmente atado à gincana, à cafeteria e à reunião de condomínio, de modo que deve ser integrado às explicações destas; 2 ) o fogo no pneu possui dignidade epistêmica intrínseca, haja vista estar inextricavelmente associado ao conjunto de relações sociais que se enquadram no conteúdo semântico da categoria poder, objeto específico da ciência política.

Sob o aspecto instrumental, é suficiente notar, para apresentar um primeiro exemplo, que o mais ortodoxo estudo de política pública que tenha como objeto a mobilidade urbana será inapto para explicar o ciclo das decisões tarifárias, senão mediante um acurado exame dos protestos entre maio e agosto de 2013 no Brasil. Da mesma maneira, a compreensão da dinâmica dos legislativos subnacionais em questões como regulação urbana e medidas habitacionais não pode prescindir de uma abordagem que seja mais do que incidental sobre os novos movimentos de ocupação e luta por moradia que ganham as cidades do Brasil, tais como o Movimento dos Trabalhadores Sem-Teto (MTST) e o Movimento Resistência Popular pelo Direito à Cidade (MRP). Um terceiro exemplo sugere que estudos de prosopografia ${ }^{16}$ das elites dirigentes de um 
partido como o Partido dos Trabalhadores (PT) demandariam um profundo esforço de compreensão dos repertórios, demandas e eventos compreendidos nas greves operárias do ABC Paulista na virada dos anos 1970 para os 1980 .

Assuntos tão institucionais como direito e políticas públicas só podem ser cientificamente compreendidos quando é levada à lente do observador a dinâmica de protestos, confrontos e lutas que não se dão necessariamente no plano da interlocução informal, da mediação representativa institucional e da participação social no Estado. O filósofo Costas Douzinas, um dos principais estudiosos contemporâneos da resistência social, é preciso ao indicar o valor instrumental dos estudos de ciência política como fogo no pneu e os riscos de se negligenciá-los, ao buscar na história a constatação de que "o voto, o voto feminino, leis básicas para a proteção do trabalho e cessação da discriminação e muitas outras garantias hoje tidas por asseguradas foram o resultado de protestos, violência e distúrbios" (Douzinas, 2013, p. 47, tradução nossa).

A relevância epistêmica da ciência política como fogo no pneu é, porém, mais do que instrumental. Há política nas lutas sociais e o seu sentido não se resume em contribuir para novas políticas públicas, inclusão de temas nas interações da esfera pública, gestação de espaços mais abertos de participação social ou reformas inclusivas nos sistemas eleitorais. Distúrbios, ocupações, greves ilegais e protestos de rua são, de fato, elemento constitutivo da política e, do tumulto maquiaveliano ao direito de resistência na gênese do liberalismo, a integram necessária e indissoluvelmente. Novamente, Costas Douzinas chama a atenção para as lacunas do campo acadêmico da ciência política, ao escrever, a propósito da onda de protestos a que o mundo assiste desde 2008, que "a ciência política padrão, obcecada com as maquinações de governos, partidos e parlamentos, não pode entender esses eventos espontâneos e os rejeita como sendo não políticos" (Douzinas, 2013, p. 47, tradução nossa). Em suma, os dados obtidos indicam que o Brasil não se excepciona à realidade percebida pelo segmento da literatura estrangeira segundo o qual a ciência política dedica pouca atenção aos movimentos sociais, em especial quando estes não se voltam a questões como promoção de políticas públicas, participação em espaços oficiais, gestão estatal ou produção legislativa (Flesher Fominaya, 2014). 


\section{Considerações finais}

Este artigo procurou acrescentar às abordagens convencionais sobre a ciência política brasileira um enfoque alegórico, que se somou às classificações já existentes e enfocou as escolhas temáticas e os olhares que definem o fazer acadêmico na disciplina ${ }^{17}$.

Sob o tom alegórico proposto, constatou-se, no que tange ao momento atualmente experimentado pela disciplina no país, que a alegoria de uma gincana explica o conceito de poder inscrito na acachapante maioria de trabalhos empíricos ou factuais publicados nos periódicos mais prestigiosos. Esse cenário, contudo, não permite apenas a otimista conclusão de que há uma estabilização do objeto, digna de contribuir para a consolidação da ciência política em suas peculiaridades diante de áreas como a sociologia, a antropologia e a psicologia social.

O certo é que a ciência política brasileira, objeto de abordagens reflexivas em geral laudatórias, está distante de se revelar uma disciplina acadêmica minimamente condizente com a abrangência do respectivo objeto, ao mesmo tempo que uma de suas centrais e mais perenes dimensões - atinente ao que aqui se chama de forma alegórica de fogo no pneu - permanece negligenciada. Mutatis mutandis, acaso a medicina se institucionalizasse ignorando questões psiquiátricas como problema para analistas, a engenharia delegasse o estudo de materiais para os químicos ou a matemática abdicasse dos seus paradoxos em favor dos filósofos, certamente haveria incômodo e irresignação. Causa surpresa, portanto, que um silêncio aquiescente acompanhe a presença inferior a $5 \%$ das publicações nos periódicos mais relevantes de um aspecto inarredável, instrumental e intrinsecamente, das relações sociais compreendidas no estudo da ciência política.

17 O uso das alegorias foi necessário porque, frequentemente, conceitos estáveis ou consolidados podem turvar, em vez de esclarecer, a realidade. Por exemplo, usar a categoria partido político para entender, no Brasil, agrupamentos que oscilam do Partido da Social Democracia Brasileira (PSDB) ao Partido Socialista dos Trabalhadores Unificado (PSTU) é uma medida pertinente e produtiva sob incontáveis aspectos, mas em determinadas situações pode levar à errônea conclusão de que se tratam de organizações da mesma natureza, quando uma concentra-se em corridas eleitorais e a outra preocupa-se com protestos ou disputas sindicais. Igualmente, considerar movimentos social grupos que se organizam para ajuizar ações coletivas e jovens aderentes à tática black bloc submete a um mesmo conceito formas políticas que, sob diversos critérios, revelam-se muito diferentes entre si. As alegorias expostas, em oposição às classificações usuais, se afiguram mais fecundas para definir o que agentes políticos fazem, antes do nome que tradicionalmente receberam. 
Em tempos de balanço e reflexão sobre a disciplina no Brasil, acrescentase à dúvida sobre a presença de um calcanhar metodológico uma certeza quanto à ocorrência de um calcanhar temático.

\section{Referências}

AMORIM NETO, Octavio (2010). "A política comparada no Brasil: a política dos outros", em LESSA, Renato (org.). Horizontes das ciências sociais no Brasil: ciência política. São Paulo: Anpocs.

ARAUJO, Cícero \& ASSUNÇÃO, San Romanelli. (2010) “Teoria política no Brasil hoje”, em LESSA, Renato (org.). Horizontes das ciências sociais no Brasil: ciência política. São Paulo: Anpocs.

AVRITZER, Leonardo (org.) (2009). Experiências nacionais de participação social. São Paulo: Cortez.

(org.) (2010). A dinâmica da participação local no Brasil. São Paulo: Cortez.

BADIOU, Alain (2012). The rebirth of history: times of riots and uprisings. London: Verso.

BIANCHI, Alvaro (2007). "Uma teoria marxista do político? O debate Bobbio trente anni doppo”. Lua Nova, n. 70, p. 39-82.

BRINGEL, Breno (2013). "Miopias, sentidos e tendências do levante brasileiro de 2013". Insight Inteligência, n. 62 [online]. http://insightnet.com. br/inteligencia/?page_id=48. Acessado em 20 abr. 2015.

CAPES - Coordenação de Aperfeiçoamento de Pessoal de Nível Superior (2015). Relatório do Seminário de Acompanhamento (Ciência Política e Relações Internacionais). Brasília: Diretoria de Avaliação da Capes.

CLARKE, Bruce (1996). "Introduction: allegory and science”. Configurations, v. 4, n.1, p. 33-7.

COELHO, Vera Schattan P. \& NOBRE, Marcos (orgs.) (2004). Participação e deliberação: teoria democrática e experiências institucionais no Brasil contemporâneo. São Paulo: Editora 34.

COELHO, Vera Schattan P.; FANTI, Fabíola \& RIBEIRO, Meire (2010). “Mobilização e participação: um jogo de soma zero?” Novos Estudos, n. 86, p. 121-39.

COLLACO, Gwedolyn (2011). The Ottoman Coffeehouse: all the charms and dangers of commonality in the 16th-17th century [online]. http://www. academia.edu/1123874/The_Ottoman_Coffeehouse_All_the_Charms_ 
and_Dangers_of_Commonality_in_the_16th-17th_Century. Acessado em 19 dez. 2014.

DAGNINO, Evelina (2004). "Construção democrática, neoliberalismo e participação: os dilemas da confluência perversa”. Política \& Sociedade, v. 1, n. 5, p. 137-61.

DELLA PORTA, Donatella (ed.) (2014). Methodological practices in social movement research. Oxford: Oxford University Press.

DOUZINAS, Costas (2013). Philophy and resistance in the crisis. Cambridge: Polity.

FERES JÚNIOR, João (2000). “Aprendendo com os erros dos outros: o que a história da ciência política americana tem para nos contar". Revista de Sociologia e Política, n. 15, p. 97-110.

FLESHER FOMINAYA, Cristina (2014). Social movements \& globalization: how protests, occupations \& uprisings are changing the world. London: Palgrave Mcmillan.

FORJAZ, Maria Cecília Espina (1997). “A emergência da ciência política no Brasil: aspectos institucionais". Revista Brasileira de Ciências Sociais, v. 12, n. 35, p. 101-20.

GOODIN, Robert E. (2009). "The state of the discipline, the discipline of the state", em The Orford handbook of political science. Oxford: Oxford University Press.

HABERMAS, Jürgen (2002). A inclusão do outro: estudos de teoria política. Trad. George Sperber. São Paulo: Loyola. (2003). Mudança estrutural da esfera pública: investigações quanto a uma categoria da sociedade burguesa. 2. ed. Trad. Flávio R. Kothe. Rio de Janeiro: Tempo Brasileiro.

(2012). Teoria do agir comunicativo. Vol. 2: Sobre a crítica da razão funcionalista. Trad. Flávio Beno Siebeneichler. São Paulo: Martins Fontes. HALL, Peter \& TAYLOR, Rosemary (2003). “Três versões do neoinstitucionalismo”. Lua Nova, n. 58, p. 193-223.

KATZNELSON, Ira \& MILNER, Helen V. (2002). "American political science: the discipline's state and the state of the discipline", em KATZNELSON, Ira \& MILNER, Helen V. (eds.). Political science: state of the discipline. New York: Norton.

KUHN, T. (1996). The structure of scientific revoltutions. 3. ed. Chicago: Chicago University Press. 
LEITE, Fernando (2010). “O campo de produção da ciência política brasileira contemporânea”, em LESSA, Renato (org.). Horizontes das ciências sociais no Brasil: ciência política. São Paulo: Anpocs.

LESSA, Renato (org.) (2010). Horizontes das ciências sociais no Brasil: ciência política. São Paulo: Anpocs.

LESSA, Renato (2011). "Da interpretação à ciência: por uma história filosófica do conhecimento político no Brasil”. Lua Nova, São Paulo, n. 82 , p. 17-60.

LIMONGI, Fernando; ALMEIDA, Maria Hermínia Tavares de \& FREITAS, Andrea (2015). "Da sociologia política ao (neo)institucionalismo: trinta anos que mudaram a ciência política no Brasil”, em AVRITZER, Leonardo \& MILANI, Carlos (orgs.). Ciência política no Brasil: história, métodos, conceitos [no prelo]. https://www.academia.edu/15209689/ DA_SOCIOLOGIA_POL\%C3\%8DTICA_AO_NEO_INSTITUCIONALISMO_TRINTA_ANOS_QUE_MUDARAM_A_CI\%C3\%8ANCIA_ POL\%C3\%8DTICA_NO_BRASIL. Acessado em 20 set. 2015.

LIMONGI, Fernando (2010). "Estudos legislativos”, em LESSA, Renato (coord.). Horizontes das ciências sociais no Brasil: ciência política. São Paulo: Anpocs.

MACADAM, Doug; TARROW, Sidney \& TILLY, Charles (2004). Dynamics of contention. Cambridge: Cambridge University Press.

MANIN, B. (1995). "As metamorfoses do governo representativo". Revista Brasileira de Ciências Sociais, v. 10, n. 29, p. 5-34.

MAQUIAVEL, N. (1994). Comentários sobre a primeira década de Tito Lívio. 3. ed. Trad. Sérgio Bath. Brasília: Editora UnB.

MAQUIAVEL, N. (1996). O príncipe. Trad. Maria Júlia Goldwasser. São Paulo: Martins Fontes.

MARCUSE, Herbert (2007). “Tolerância repressiva”. Trad. Kathlen Luana de Oliveira. Protestantismo em Revista, v. 12, p. 28-58.

MARQUES, Danusa \& MACHADO, Carlos (2014). "Democracia e desigualdades nas ciências sociais brasileiras: artigos públicados entre 2000 e 2010”. IX Encontro Nacional da ABCP. Brasília, 4-7 ago.

MIGUEL, Luis Felipe \& FEITOSA, Fernanda (2009). "O gênero do discurso parlamentar: mulheres e homens na tribuna da Câmara dos Deputados». Dados: Revista de Ciências Sociais, v. 52, n.1, p. 201-21. 
MOREIRA, Marcelo Sevaybricker (2012). "O debate teórico-metodológico na ciência política e o pensamento social e político brasileiro". Teoria \& Pesquisa, v. 21, n. 1, p. 73-89.

MUSSI, Daniela Xavier H. (2014). "Uma ciência política para um Brasil democrático”. IX Simpósio Nacional sobre Democracia e Desigualdades. Brasília, 7-9 maio.

NICOLAU, Jairo \& OLIVEIRA, Lilian (2013). "Produção da Ciência Política Brasileira: Uma análise dos artigos acadêmicos”. $37^{\circ}$ Encontro Nacional da Anpocs. Águas de Lindóia. Anais... Águas de Lindóia (SP),.

OPP, Karl-Dieter (2009). Theories of political protest and social movements: a multidisciplinary introduction, critique and synthesis. London: Routledge. PATEMAN, Carole (1992). Participação e teoria democrática. Trad. Luiz Paulo Rouanet. Rio de Janeiro: Paz e Terra.

LEITE, Fernando (2015). O campo de produção da ciência política brasileira contemporânea: uma análise histórico-estrutural de seus princípios de divisão a partir de periódicos, áreas e abordagens. Tese (doutorado) em sociologia. Curitiba: UFPR.

PIROZELLI, Paulo; SIMONI JR., Sergio \& SILVA, Fábio Lacerda (2012). "Reflexões epistemológicas sobre a ciência política brasileira". VIII Encontro Nacional da ABCP. Gramado (RS), 1-4 ago.

POGREBINSCHI, Thamy \& SANTOS, Fabiano (2011). "Participação como representação: o impacto das conferências nacionais de políticas públicas no congresso nacional". Dados, v. 54, n. 3, p. 259-305.

ROUSSEAU, J. J. (2002). Do contrato social [online]. Trad. Rolando R. da Silva. http://www.dominiopublico.gov.br/download/texto/cv00014a.pdf. Acessado em 28 set. 2015.

SANTOS, Boaventura de Sousa (2006). A gramática do tempo: para uma nova cultura política. São Paulo: Cortez.

SANTOS, Boaventura de Sousa \& AVRITZER, Leonardo (2002). "Introdução: para ampliar o cânone democrático", em SANTOS, Boaventura de Sousa (org). Democratizar a democracia: os caminhos da democracia participativa. Rio de Janeiro: Civilização Brasileira.

SARMENTO, Rayza; REIS, Stephanie \& MENDONÇA, Ricardo Fabrino (2015). "As jornadas de junho e a questão de gênero: as idas e vindas das lutas por justiça”. VI Congresso Compolítica. Rio de Janeiro, 22-24 abr. 
SCIMAGO (2015). Country rankings: political science and international relations (Latin Amrica) [online]. http://www.scimagojr.com/countryrank. php area $=3300 \&$ category $=3320 \&$ region $=$ Latin + America\&year $=2014 \&$ order=it\&min=0\&min_type=it. Acessado em 12 ago. 2015.

SILVEIRA, Sérgio Amadeu \& PIMENTEL, Tiago. (2013). "Cartografia de Espaços Híbridos: as manifestações de junho de 2013” [online]. http:// interagentes.net/?p=62. Acessado em 20 jun. 2014.

SIMITI, Marilena (2011). "Violence in riots and social movements". 6th European Consortium for Political Research (ECPR) General Conference. Reykjavík, 25-27 ago.

SOARES, Gláucio (2005). “O calcanhar metodológico da ciência política no Brasil”. Sociologia: Problemas e Práticas, n. 48, p. 27-52.

STEENBERGEN, Marco; BÄCHTIGER, André; SPÖRNDLI Markus \& STEINER, Jürg (2003). "Measuring political deliberation: a discourse quality index". Comparative European Politics, n. 1, p. 21-48.

STONE, Lawrence (2011). "Proposografia”. Revista de Sociologia e Política, v. 19, n. 39 , p. 115-37.

TAVARES, Francisco M. M. \& RORIZ, João Henrique R. (2015). «Avant juin, les rues de mai. Étude de cas sur les manifestations en faveur de la mobilité urbaine dans la ville de Goiânia». Brésil(s), n. 7, p. 77-101. WEBER, Max (2008). "A política como vocação", em Ensaios de Sociologia. 5. ed. Trad. Waltensir Dutra. Org. H. H. Gerth e C. Wright Mills. Rio de Janeiro: LTC.

WEINGAST, Barry R. (2002). "Rational-choice institutionalism”, em KATZNELSON, Ira \& MILNER, Helen V. (eds). Political science: state of the discipline. New York: Norton.

WOOD, Ellen (2012). Liberty and property: a social history of western political thought from the renaissance to enlightenment. London: Verso. YOUNG, Iris Marion (2001). "Activist challenges to deliberative democracy". Political Theory, v. 29, n.5, p. 670-90.

\section{Resumo}

O artigo parte do contexto de autorreflexão vivido pela ciência política no Brasil e identifica os principais trabalhos que contribuíram, nos últimos anos, para esse processo. Em seguida, propõe uma nova classificação para os tipos de pesquisa realizados na área, com uso de formas alegóricas que perfazem quatro tipos ideais. Avalia-se, então, 
a distribuição de cada tipo em meio à produção científica recente, sob a hipótese de que eles são igualmente relevantes e devem se distribuir de modo equilibrado entre os artigos publicados. Descobre-se, contudo, que há uma desproporcional prevalência de estudos associados a um só tipo alegórico e uma presença ínfima de trabalhos correspondentes àquele relacionado com a pesquisa sobre lutas, protestos e conflitos sociais. Identifica-se, assim, o caráter precário e estreito do espectro de temas pesquisados pela ciência política brasileira, a comprometer sua consolidação como campo acadêmico e sua solidez epistêmica.

Palavras-chave: ciência política brasileira, epistemologia das ciências sociais, alegorias em ciência, seletividades temáticas.

\section{Abstract}

This article departs form the context of self-reflexion that Brazilian Political Science faces nowadays and mentions the most important publications related to such a task. Subsequently, it is presented a new, allegory-based, typology for the 4 main kinds of social phenomena studied by different political scientists in Brazil. Then, the frequency of each type among recent publications is measured. The hypothesis is that, since the types are equally important and mutually relevant to each other, there should be a proportional distribution of each one among the publications. However, it is found that one type is immensely more studied than the others. Besides, the type related to protests, struggles and social conflicts is rather neglected. The precarious and narrow range of issues researched by Brazilian Political Science is, therefore, identified as a feature that hurts the field's consolidation and epistemic solidity.

Keywords: Brazilian political science, social sciences' epistemology, allegories in science, thematic selectivities.

Recebido em 30 de setembro de 2015.

Aprovado em 3 de março de 2016. 